\title{
EKSPERIMENTASI MODEL PEMBELAJARAN KOOPERATIF TIPE GROUP INVESTIGATION (GI) DAN THINK PAIR AND SHARE (TPS) PADA MATERI SISTEM PERSAMAAN LINEAR DITINJAU DARI SIKAP MAHASISWA TERHADAP MATEMATIKA
}

\author{
Swasti Maharani \\ Program Studi Pendidikan Matematika FPMIPA IKIP PGRI Madiun \\ Email : swastimaharani@yahoo.com
}

\begin{abstract}
Abstrak. Tujuan dari penelitian ini adalah untuk mengetahui : ( 1 ) yang model GI , TPS atau hasil pembelajaran konvensional pada prestasi belajar yang lebih baik dalam belajar matematika, (2) yang siswa kelas sikap terhadap matematika positif, netral, atau negatif hasil jenis dalam prestasi belajar yang lebih baik dalam matematika, (3 ) pada masingmasing siswa kelas sikap terhadap matematika, yang model GI pembelajaran, TPS atau hasil pembelajaran konvensional pada prestasi belajar yang lebih baik dalam matematika, dan ( 4 ) di masing-masing model pembelajaran, yang siswa kelas sikap terhadap matematika positif, netral, atau negatif hasil jenis dalam prestasi belajar yang lebih baik dalam matematika. Penelitian ini menggunakan metode penelitian eksperimen kuasi dengan desain faktorial $3 \times 3$. Populasinya adalah semua siswa kelas di IKIP PGRI Madiun semester V 2013/2014 . Sampel penelitian diambil dengan menggunakan teknik cluster random sampling . Data penelitian dianalisis dengan menggunakan analisis dua arah tidak seimbang varians pada tingkat signifikansi $5 \%$. Hasil penelitian ini menunjukkan bahwa : ( 1 ) model pembelajaran GI dan TPS menghasilkan prestasi belajar yang baik yang sama dalam matematika, namun kedua hasil dalam prestasi belajar yang lebih baik dalam matematika dibandingkan dengan model pembelajaran konvensional , (2) prestasi belajar matematika dengan sikap positif terhadap matematika adalah lebih baik dari itu dengan sikap netral dan negatif terhadap matematics, bahwa dengan sikap netral terhadap matematics adalah lebih baik dari itu dengan sikap negatif terhadap matematika, (3 ) pada masing-masing siswa sikap terhadap jenis matematika, GI dan model pembelajaran TPS hasil dalam pencapaian yang sama baik belajar di matematika, tapi baik mengakibatkan prestasi belajar yang lebih baik dalam matematika daripada model pembelajaran konvensional , (4) pada masing-masing model pembelajaran , prestasi belajar dengan sikap positif terhadap matematika matematika adalah lebih baik dari itu dengan netral dan sikap negatif terhadap matematics, bahwa dengan sikap netral terhadap matematics adalah lebih baik dari itu dengan sikap negatif terhadap matematika .
\end{abstract}

Kata kunci: model pembelajaran , GI , TPS , konvensional , siswa sikap terhadap matematika

\section{PENDAHULUAN}

Pendidikan merupakan masalah yang penting bagi manusia karena menyangkut kelangsungan hidup manusia dan tingkat kecerdasan bangsa. Salah satu ilmu yang berperan penting dalam kehidupan adalah matematika, dimana matematika merupakan dasar komponen penting bagi bidang ilmu sains lainnya. Mahanta

berpendapat sebagai berikut.

"The study of mathematics is considered to be very important in each and every country of the world. Students are required to learn mathematics which is considered as a basic education, since the skill of mathematics computation is essential in every walk of life". 
Belajar matematika dianggap sangat penting bagi setiap negara di dunia. Siswa diminta untuk belajar matematika yang dianggap sebagai pendidikan dasar, karena keterampilan perhitungan matematika sangat penting dalam setiap langkah kehidupan. Namun perkembangan pembelajaran matematika di Indonesia masih jauh dari harapan. Praktek pembelajaran matematika di Indonesia selama ini masih berpusat pada guru. Guru menyampaikan pelajaran dengan menggunakan metode ceramah dan siswa mencatatnya pada buku catatan. Selain itu kebanyakan siswa di sekolah beranggapan bahwa belajar matematika tidak menyenangkan dan hanya menjadi rutinitas tanpa diiringi kesadaran untuk menambah wawasan. Padahal matematika itu sendiri sangat berguna dalam kehidupan seharihari. Matematika dipelajari mulai anak pra sekolah hingga perguruan tinggi. Namun secara umum kondisi pembelajaran matematika di IKIP PGRI Madiun khususnya pada program studi pendidikan matematika belum sesuai harapan. Berdasarkan data nilai Ujian Akhir Semester (UAS) Program Studi Pendidikan Matematika menunjukkan bahwa rata-rata nilai matematika pada UAS tahun 2012 masih rendah khususnya pada mata kuliah Aljabar Linear. Di dalam Aljabar Linear, mahasiswa diperkenalkan dengan sistem persamaan linear beserta solusinya. Pada umumnya masih banyak mahasiswa yang kesulitan dalam menyelesaikan permasalahan yang berkaitan dengan solusi sistem persamaan linear. Hal tersebut terlihat pada nilai rata-rata UAS pada mata kuliah Aljabar Linear tahun 2012 masih rendah yaitu 59.

Oleh karena itu diperlukan adanya pembaharuan dalam bidang pendidikan. Salah satu pembaharuan yang dapat dilakukan adalah dengan meningkatkan kualitas pembelajaran. Keberhasilan mahasiswa dalam belajar bergantung pada cara penyajian materi pelajaran dan model pembelajaran yang digunakan oleh dosen. Jika pembelajaran tersebut monoton dan lecture centered tentunya sangat membosankan bagi mahasiswa. Oleh karena itu diperlukan model pembelajaran yang bisa meningkatkan keberhasilan belajar mahasiswa. Faktor lain yang mempengaruhi keberhasilan belajar diantaranya adalah sikap mahasiswa terhadap matematika. Menurut Borasi (dalam Mohd and Farah, 2011) "The conceptions, attitudes, and expectations of students regarding mathematics and mathematics teaching have been considered to be very significant factor underlying their school experience and achievement". Konsepsi, sikap, dan harapan siswa tentang matematika dan pembelajaran matematika telah dianggap sebagai faktor yang sangat penting yang mendasari pengalaman dan prestasi mereka di sekolah. Selanjutnya, Hoang (2008) mengemukakan "there is strong evidence of associations between students' attitudes and the learning environment". Terdapat hubungan yang kuat antara sikap siswa dan lingkungan belajar. Selain itu penelitian yang dilakukan oleh Akinsola and Olowojaiye (2008) yang mengemukakan "teachers' method of instruction in classroom is important in changing students' attitude and habits towards mathematics". Metode guru dalam penyampaian pembelajaran di kelas sangat penting dalam mengubah sikap dan kebiasaan terhadap matematika. Salah satu model pembelajaran yang dapat digunakan adalah model pembelajaran kooperatif yang mana siswa membentuk kelompokkelompok dalam pembelajaran, sehingga 
siswa mengalami perubahan suasana belajar. Sejalan dengan hasil penelitian Zakaria, Chin and Daud (2010) yang mengemukakan "cooperative learning is an effective approach and can improve students' achievement in mathematics and attitude towards mathematics, which mathematics teachers need to incorporate in their teaching". Pembelajaran kooperatif merupakan pendekatan yang efektif dan dapat meningkatkan prestasi siswa dalam matematika dan sikap terhadap matematika, yang guru matematika perlu untuk memasukkan ke dalam pembelajaran mereka. Oleh karena itu penggunaan model pembelajaran kooperatif tipe GI dan TPS menarik untuk diteliti.

Berdasarkan uraian yang dikemukakan di atas, tujuan yang ingin dicapai pada penelitian ini adalah untuk mengetahui: (1) manakah diantara model pembelajaran (GI, TPS, atau Konvensional) yang memberikan prestasi belajar matematika yang lebih baik pada materi sistem persamaan linear; (2) manakah sikap mahasiswa terhadap matematika yang memberikan prestasi belajar matematika yang lebih baik, sikap positif, netral atau negatif terhadap matematika; (3) pada masing- masing sikap mahasiswa terhadap matematika, manakah yang memberikan prestasi belajar matematika lebih baik, model pembelajaran GI, TPS, atau Konvensional; (4) pada masing-masing model pembelajaran, manakah yang memberikan prestasi belajar matematika lebih baik, sikap positif, netral atau negatif terhadap matematika.

\section{METODE PENELITIAN}

Penelitian ini merupakan penelitian eksperimental semu dengan desain faktorial $3 \times 3$. Analisis data dilakukan dengan Anava dua jalan dengan sel tak sama dengan taraf signifikansi 5\%. Populasi penelitian adalah mahasiswa calon guru matematika semester V IKIP PGRI Madiun Tahun Akademik 2013/2014 . Penelitian dilakukan di kelas VB sebagai kelas eksperimen model pembelajaran GI, VC sebagai kelas eksperimen model pembelajaran TPS, dan VE sebagai kelas kontrol model pembelajaran Konvensional.

Uji normalitas menggunakan metode Lilliefors dan diperoleh hasil bahwa ketiga kelompok berasal dari populasi yang berdistribusi normal. Hal tersebut dapat dilihat pada Tabel 1 berikut.

Tabel 1. Rangkuman Hasil Uji Normalitas

untuk Data Nilai Kemampuan Awal Mahasiswa VB, VC dan VE

\begin{tabular}{ccccc}
\hline Pembelajaran & $L$ Observasi & $L$ Kritik & Keputusan Uji & $\begin{array}{c}\text { Data } \\
\text { berdistribusi }\end{array}$ \\
\hline GI & 0,0669 & 0,1010 & $H_{0}$ Diterima & Normal \\
TPS & 0,0960 & 0,0997 & $H_{0}$ Diterima & Normal \\
Konvensional & 0,0704 & 0,0997 & $H_{0}$ Diterima & Normal
\end{tabular}

Uji homogenitas menggunakan uji Bartlett, diperoleh hasil bahwa ketiga kelompok mempunyai variansi homogen $\left(\chi^{2}\right.$ Observasi $=0,9282<5,9910=\chi^{2}$ Kritik). Uji keseimbangan rataan menggunakan anava satu jalan dan diperoleh $\quad F_{o b s}=$ $0,5879<3,0000=F_{\text {tabel }}$. Hal ini menunjukkan bahwa ketiga kelompok memiliki kemampuan awal yang sama atau seimbang.

Teknik pengumpulan data adalah: (1) metode tes; (2) metode dokumentasi; dan (3) metode angket. Instrumen penelitian terdiri atas: (1) tes prestasi; (2) angket sikap mahasiswa terhadap matematika.

Variabel terikat adalah prestasi mahasiswa pada materi sistem persamaan linear, sedangkan variabel 
bebasnya adalah model pembelajaran yang terbagi atas model pembelajaran GI pada kelas eksperimen pertama, model pembelajaran TPS pada kelas eksperimen kedua, dan model pembelajaran Konvensional pada kelas kontrol. Variabel bebas yang lain adalah sikap mahasiswa terhadap matematika dengan kategori sikap positif, netral dan negatif terhadap matematika.

Uji coba instrumen dilakukan pada mahasiswa calon guru matematika VA IKIP PGRI Madiun dengan responden 30 mahasiswa. Untuk instrumen tes prestasi, mengacu pada kriteria yaitu validitas isi, daya pembeda $(\mathrm{D} \geq 0,3)$, tingkat kesukaran $(0,25 \leq \mathrm{P} \leq 0,75)$, dan reliabilitas $\left(r_{x y}>0,70\right)$. Dari 30 butir soal yang diujicobakan diperoleh 25 butir soal yang baik, sehingga dapat digunakan sebagai instrumen penelitian tes prestasi mahasiswa. Untuk uji coba angket sikap mahasiswa terhadap matematika, mengacu pada kriteria yaitu validitas isi, reliabilitas dengan rumus Alpha $\left(r_{11}>0,70\right)$ dan konsistensi internal $\left(r_{x y} \geq 0,3\right)$. Dari 30 butir angket yang diujicobakan diperoleh 28 butir angket yang baik. Uji prasyarat analisis yaitu uji normalitas dengan metode Lilliefors dan uji homogenitas dengan uji Bartlett. Diperoleh prasyarat normalitas dan homogenitas data telah terpenuhi, sehingga dapat dilakukan analisis data menggunakan anava dua jalan dengan sel tak sama dan uji komparasi ganda menggunakan metode Scheffe'. Uji Normalitas dan homogenitas dapat dilihat pada Tabel 2 dan Tabel 3 berikut.

Tabel 2. Rangkuman Hasil Uji Normalitas

\begin{tabular}{ccccc}
\hline Populasi Mahasiswa & L Observasi & $\begin{array}{c}L \\
\text { Kritik }\end{array}$ & Keputusan Uji & $\begin{array}{c}\text { Data } \\
\text { Berdistribusi }\end{array}$ \\
\hline GI & 0,0877 & 0,0997 & $\mathrm{H}_{0}$ Diterima & Normal \\
TPS & 0,0645 & 0,1010 & $\mathrm{H}_{0}$ Diterima & Normal \\
Konvensional & 0,0585 & 0,0997 & $\mathrm{H}_{0}$ Diterima & Normal \\
Sikap Positif & 0,0847 & 0,0924 & $\mathrm{H}_{0}$ Diterima & Normal \\
Sikap Netral & 0,0609 & 0,1134 & $\mathrm{H}_{0}$ Diterima & Normal \\
Sikap Negatif & 0,0650 & 0,0978 & $\mathrm{H}_{0}$ Diterima & Normal \\
\hline
\end{tabular}

Tabel 3. Rangkuman Hasil Uji Homogenitas Variansi

\begin{tabular}{ccccc}
\hline Populasi Mahasiswa Antar & $\chi^{2}$ Observasi & $\chi^{2}$ Kritik & Keputusan Uji & Kesimpulan \\
\hline Pembelajaran & 1,0256 & 5,9910 & $\mathrm{H}_{0}$ Diterima & Homogen \\
$\begin{array}{c}\text { Sikap Mahasiswa Terhadap } \\
\text { Matematika }\end{array}$ & 0,4163 & 5,9910 & $\mathrm{H}_{0}$ Diterima & Homogen \\
\hline
\end{tabular}

\section{HASIL PENELITIAN DAN PEMBAHASAN}

Rangkuman hasil analisis anava dua jalan dapat dilihat pada Tabel 4 dan rangkuman komparasi ganda dapat dilihat pada Tabel 5 dan Tabel 6.

Tabel 4. Rangkuman Analisis Variansi Dua Jalan

\begin{tabular}{ccccccc}
\hline Sumber & JK & dk & RK & Fobs & F tabel & Kesimpulan \\
\hline $\begin{array}{c}\text { Model Pembelajaran } \\
\text { (A) }\end{array}$ & 2655,2694 & 2 & 1327,635 & 5,5297 & 3,0000 & $\begin{array}{c}\mathrm{H}_{0 \mathrm{~A}} \\
\text { ditolak }\end{array}$ \\
$\begin{array}{c}\text { Sikap Mahasiswa } \\
\text { Terhadap Matematika } \\
\text { (B) }\end{array}$ & 1532,9107 & 2 & 766,4554 & 3,1924 & 3,0000 & $\begin{array}{c}\mathrm{H}_{0 \mathrm{~B}} \\
\text { ditolak }\end{array}$ \\
$\begin{array}{c}\text { Interaksi (AB) } \\
\text { Galat }\end{array}$ & 1628,4599 & 4 & 407,115 & 1,6957 & 2,3700 & $\mathrm{H}_{0 \mathrm{AB}}$ diterima \\
Total & 54260,231 & 94 & 240,0895 & & & \\
\hline
\end{tabular}


Tabel 5. Rangkuman Komparasi Ganda Antar Baris

\begin{tabular}{cccc}
\hline $\mathrm{H}_{0}$ & $\mathrm{~F}_{\text {obs }}$ & $2 \mathrm{~F}_{0,05 ; 2,232}$ & Keputusan \\
\hline$\mu_{1 .}=\mu_{2 .}$ & 1,5267 & $(2)(3,00)=6,00$ & $\mathrm{H}_{0}$ diterima \\
$\mu_{2 .}=\mu_{3 .}$ & 94,3041 & $(2)(3,00)=6,00$ & $\mathrm{H}_{0}$ ditolak \\
$\mu_{1 .}=\mu_{3 .}$ & 70,7784 & $(2)(3,00)=6,00$ & $\mathrm{H}_{0}$ ditolak \\
\hline
\end{tabular}

Tabel 6. Rangkuman Komparasi Ganda Antar Kolom

\begin{tabular}{cccc}
\hline $\mathrm{H}_{0}$ & $\mathrm{~F}_{\mathrm{obs}}$ & $2 \mathrm{~F}_{0,05 ; 2,232}$ & Keputusan \\
\hline$\mu_{\cdot 1}=\mu_{\cdot 2}$ & 21,6922 & $(2)(3,00)=6,00$ & $\mathrm{H}_{0}$ ditolak \\
$\mu_{\cdot 1}=\mu_{\cdot 3}$ & 69,7277 & $(2)(3,00)=6,00$ & $\mathrm{H}_{0}$ ditolak \\
$\mu_{\cdot 2}=\mu_{\cdot 3}$ & 8,7149 & $(2)(3,00)=6,00$ & $\mathrm{H}_{0}$ ditolak \\
\hline
\end{tabular}

Berdasarkan hasil analisis uji hipotesis pertama $\mathrm{F}_{\mathrm{obs}}=5,5297$ lebih dari $\mathrm{F}_{\text {tabel }}=3,000$ menunjukkan bahwa $\mathrm{H}_{0 \mathrm{~A}}$ ditolak artinya terdapat perbedaan prestasi mahasiswa antara kelas model pembelajaran GI, TPS dan Konvensional. Dari uji lanjut pasca anava diperoleh kesimpulan bahwa prestasi mahasiswa dengan model pembelajaran GI sama baiknya dengan mahasiswa dengan model pembelajaran TPS, tetapi lebih baik dibandingkan mahasiswa dengan model pembelajaran Konvensional. Kesamaan prestasi belajar yang dihasilkan oleh model pembelajaran GI dan TPS, dimungkinkan karena kedua model pembelajaran tersebut merupakan pembelajaran kooperatif, di mana dalam proses pembelajaran mahasiswa diarahkan untuk bekerja sama dengan teman-temannya dalam satu kelompok. Nurhadi (2004:112) berpendapat bahwa pembelajaran kooperatif adalah pendekatan pembelajaran yang berfokus pada penggunaan kelompok kecil siswa untuk bekerja sama dalam memaksimalkan kondisi belajar untuk mencapai tujuan belajar. Didukung hasil penelitian Zakaria, Chin and Daud (2010) yang mengemukakan bahwa cooperative learning is an effective approach and can improve students' achievement in mathematics and attitude towards mathematics, which mathematics teachers need to incorporate in their teaching. Pembelajaran kooperatif merupakan pendekatan yang efektif dan dapat meningkatkan prestasi siswa dalam matematika dan sikap terhadap matematika, yang guru matematika perlu untuk memasukkan ke dalam pembelajaran mereka. Oleh karena itu siswa dengan pembelajaran GI dan TPS memiliki prestasi lebih baik daripada siswa dengan pembelajaran konvensional. Hal ini sejalan dengan penelitian Yuli Irfan Aliurido (2008) yang mengemukakan bahwa pembelajaran matematika dengan menggunakan model pembelajaran GI memberikan prestasi belajar yang lebih baik dibandingkan dengan pembelajaran matematika dengan menggunakan model pembelajaran tradisional (konvensional) pada materi pokok persamaan dan fungsi kuadrat.

Berdasarkan hasil analisis uji hipotesis kedua $F_{b}=3,1924>3,0000=$ $F_{\text {tabel }}$ dan $\quad F_{b} \in D K$ maka $H_{0} B$ ditolak. Berarti siswa dengan sikap positif, netral dan negatif terhadap matematika tidak semua prestasinya sama. Dari uji lanjut pasca anava diperoleh simpulan bahwa prestasi mahasiswa dengan sikap positif terhadap matematika mempunyai prestasi belajar yang lebih baik dibandingkan mahasiswa dengan sikap netral dan negatif terhadap matematika, mahasiswa 
dengan sikap netral terhadap matematika mempunyai prestasi belajar lebih baik dibandingkan mahasiswa dengan sikap negatif terhadap matematika. Sikap terhadap matematika merupakan sikap siswa terhadap matematika yaitu keadaan internal siswa, berupa kecenderungan atau kesiapan memberikan respon meliputi komponen kognitif, afektif dan konatif terhadap matematika atau pembelajaran matematika (Rusgianto, 2006:9). Oleh karena itu prestasi mahasiswa dengan sikap positif terhadap matematika lebih baik daripada prestasi mahasiswa dengan sikap netral dan negatif terhadap matematika, begitu juga prestasi mahasiswa dengan sikap netral terhadap matematika lebih baik daripada prestasi mahasiswa dengan sikap negatif terhadap matematika. Hal ini sejalan dengan penelitian yang dilakukan Dewi Kurniawati (2012) mengemukakan bahwa prestasi tata bahasa siswa yang memiliki sikap positif lebih baik daripada mereka yang memiliki sikap negatif.

Berdasarkan hasil analisis uji hipotesis ketiga $F_{o b s}<F_{0,05 ; 4,243}$ atau $F_{a b}=1,6957<2,3700=F_{\text {tabel. }}$ Nilai $F_{a b}$ tidak terletak di daerah kritik, sehingga $H_{0} A B$ dterima artinya tidak terdapat interaksi antara pembelajaran dan sikap mahasiswa terhadap matematika terhadap prestasi belajar matematika mahasiswa pada materi sistem persamaan linear. Berdasarkan sikap mahasiswa terhadap matematika, bahwa pada mahasiswa dengan sikap positif, netral dan negatif terhadap matematika menunjukkan prestasi mahasiswa dengan model pembelajaran kooperatif tipe GI sama baiknya dengan prestasi mahasiswa dengan model pembelajaran kooperatif tipe TPS, tetapi lebih baik daripada prestasi belajar matematika mahasiswa dengan pembelajaran konvensional.

Dari analisis variansi dua jalan diputuskan bahwa $\mathrm{H}_{0 \mathrm{AB}}$ diterima, sehingga tidak perlu dilakukan uji lanjut pasca analisis variansi dengan metode Scheffe' untuk analisis variansi dua jalan. Berdasarkan simpulan hipotesis pertama dan hipotesis kedua, maka dapat disimpulkan bahwa pada masingmasing model pembelajaran yaitu GI, TPS dan konvensional menunjukkan bahwa mahasiswa dengan sikap positif terhadap matematika mempunyai prestasi lebih baik daripada mahasiswa dengan sikap netral dan negatif terhadap matematika, mahasiswa dengan sikap netral terhadap matematika mempunyai prestasi lebih baik daripada mahasiswa dengan sikap negatif terhadap matematika.

\section{SIMPULAN DAN SARAN}

Berdasarkan hasil penelitian dan analisa data yang telah dilakukan, maka dapat disimpulkan sebagai berikut.

1. Pada materi sistem persamaan linear, prestasi mahasiswa dengan model pembelajaran kooperatif tipe GI sama dengan prestasi maha siswa dengan model pembelajaran kooperatif tipe TPS dan lebih baik daripada prestasi maha siswa dengan pembelajaran konvensional.

2. Pada materi sistem persamaan linear, prestasi mahasiswa dengan sikap positif terhadap matematika lebih baik daripada prestasi mahasiswa dengan sikap netral maupun negatif terhadap matematika. Prestasi mahasiswa dengan sikap netral terhadap matematika lebih baik daripada prestasi mahasiswa dengan sikap negatif terhadap matematika.

3. Pada materi sistem persamaan linear, pada masing-masing sikap mahasiswa terhadap matematika yaitu sikap positif, netral dan negatif, prestasi belajar matematika siswa dengan model pembelajaran kooperatif tipe GI sama dengan prestasi belajar matematika siswa dengan model pembelajaran kooperatif tipe TPS dan lebih baik daripada prestasi mahasiswa dengan pembelajaran konvensional. 
4. Pada materi sistem persamaan linear, pada masing-masing pembelajaran yaitu GI, TPS maupun pembelajaran konvensional, prestasi mahasiswa dengan sikap positif terhadap matematika lebih baik daripada prestasi mahasiswa dengan sikap netral maupun negatif terhadap matematika, prestasi mahasiswa dengan sikap netral terhadap matematika lebih baik daripada prestasi mahasiswa dengan sikap negatif terhadap matematika.

Berdasarkan hasil penelitian guru/dosen sebaiknya memilih model pembelajaran yang paling sesuai untuk diterapkan dalam proses pembelajaran, misalnya dengan menggunakan model pembelajaran GI atau TPS, karena dalam hasil penelitian menunjukkan bahwa model pembelajaran GI atau TPS memberikan prestasi belajar yang lebih baik dibandingkan pembelajaran konvensional. Selain itu guru/dosen sebaiknya memperhatikan sikap masingmasing siswa/mahasiswa terhadap matematika, karena sikap siswa/mahasiswa terhadap matematika mempengaruhi prestasi belajar, seperti yang ditunjukkan pada penelitian ini bahwa prestasi mahasiswa dengan sikap positif terhadap matematika lebih baik daripada prestasi mahasiswa dengan sikap netral maupun negatif terhadap matematika dan prestasi mahasiswa dengan sikap netral terhadap matematika lebih baik daripada prestasi mahasiswa dengan sikap negatif terhadap matematika.

\section{DAFTAR PUSTAKA}

Akinsola, M. K. and Olowojaiye, F. B. 2008. Teacher Instructional Methods and Student Attitudes Towards Mathematics. International Electronic Journal of Mathematics Education.3(1):60-73
Deen, I. and Smith, B. P. 2006.Contextual Teaching Learning and Practices In The Family and Consumer Science Curriculum. Journal of Family and Consumer Sciences Education.24(1):1427

Dewi Kurniawati. 2013. Efektivitas Menggunakan YouTube Video dalam Pengajaran Tata Bahasa Inggris Ditinjau dari Sikap Mahasiswa (Sebuah Penelitian Eksperimental di Semester I Mahasiswa Pendidikan Bahasa Inggris dari Institut Agama Islam Negeri Raden Intan Lampung pada Tahun Akademik 2012/2013).Tesis.Surakarta: PPs

Hanafiah dan Cucu Suhana.2012.Konsep Strategi

Pembelajaran.Bandung:Refi ka Aditama

Hoang, T. N. 2008. The Effects Of Grade Level, Gender, and Ethnicity On Attitude and Learning Environment In Mathematics In High School. International Electronic Journal of Mathematics Education.3(1):47-58

Mahanta, D. 2012. Achievement in Mathematics: Effect of Gender and Positive/Negative Attitude of Students. International Journal of Theoretical \& Applied Sciences,4(2):157163

Mohd, N. and Farah, T. 2011. The Effects of Attitude Towards Problem Solving in Mathematics Achievements. 
Australian Journal of Basic

and

Applied

Sciences,5(12):1857-1862

Nurhadi.2004.Kurikulum

2004.Jakarta:PT Grasindo

Rusgianto.2006.Hubungan Antara Sikap

Terhadap Matematika,

Kecerdasan Emosional

Dalam Interaksi Sosial Di Kelas Dengan Hasil Belajar Matematika Siswa Smp Negeri 5 Yogyakarta Tahun 2006.Makalah yang disampaikan pada Seminar Nasional Matematika dan Pendidikan Matematika 2006 dengan tema "Trend Penelitian dan Pembelajaran Matematika di Era ICT “ yang diselenggarakan pada tanggal24 Nopember 2006

Yuli Irvan Aliurido. 2008.

Pembelajaran Group Investigationn (GI) Pada Materi

Pokok Persamaan dan Fungsi Kuadrat Ditinjau Dari Motivasi Belajar Siswa. Tesis. Surakarta: PPs

Zakaria, E., Chin, L. C. and Daud, M. Y. 2010. The Effects of Cooperative Learning on Students' Mathematics Achievement and Attitude towards Mathematics. Journal of Social Sciences, 6(2):272-275 